\title{
Regulating Degeneracy: Eugenic Sterilization in Iowa, 1911-1977
}

\section{AMY VOGEL}

IN 1929 the Iowa General Assembly created a Board of Eugenics to investigate persons who were a "menace to society," so that such "degenerates" could be sterilized. Between then and 1977, when the legislature voted unanimously to abolish the board, it authorized the sterilization of more than two thousand individuals, three-fourths of them women. ${ }^{1}$

The Iowa eugenics movement was part of a national and, indeed, international concern about the potential social costs of allowing defective genes to proliferate in the human gene pool. Progressive attitudes in the decades after the turn of the century made it seem possible and advisable to use the power of the state to control procreation. Iowa's first sterilization laws in 1911 and 1915 reflected a national tendency to use sterilization as a punitive measure for habitual criminals and patients of the state's hospitals for the insane. With the establishment of the Board of Eugenics, Iowa's official policy in the years before

I thank the Iowa Department of Human Services for helping me gain access to the records of the State Board of Eugenics, which are held in the State Archives in Des Moines. In conformity with their requirements, all personal data regarding Board of Eugenics patients have been kept confidential. The individuals referred to in this paper have been assigned pseudonyms. I also thank Susan Lawrence for assisting me with earlier drafts.

1. Code of Iowa (1931), sec. 2437; Minutes, Statistics, and Agendas, 1956-1976, Iowa Board of Eugenics Records, State Archives, State Historical Society of Iowa, Des Moines.

THE ANNALS OF IOWA 54 (Winter 1995). CThe State Historical Society of Iowa, 1995. 
World War II reflected more concern with controlling the effects of procreation among socially dependent classes of people. After the war, traditional eugenics lost credibility nationwide among established birth control organizations and in the medical community. At the same time, however, new forms of advocacy led to an increase in the number of sterilizations authorized in Iowa: during the peak years of the late 1940s and early 1950s, the board approved more than one hundred sterilizations per year. In the 1960s and 1970s, however, pressures mounted from the medical and scientific communities, and the white, middle-class cultural standard that provided the ideological foundation for the eugenics movement came under increasing attack. As a result, the board gradually decreased its activities and eventually called for its own dissolution.

THE EUGENICS MOVEMENT emerged in the late nineteenth century, as social activism combined with a commitment to scientific progress. The concept of eugenics can be traced to antiquity, but modern eugenics was a product of Darwinism and Mendel's basic laws of inheritance, as well as an idealized faith in science and human progress that characterized the late nineteenth century. The term eugenics, meaning "well born," was coined by Sir Francis Galton, a British scientist and prolific Victorian writer. Galton founded the movement and philosophy, which promised to improve the human species through better breeding. Convinced that human abilities were inherited rather than acquired, Galton sought to explain the variety of physical and psychological human traits. This work, Galton concluded, enabled one to determine the inherent value of a person to society. $^{2}$

Galton's conclusions had fundamental implications for social reform and public policies. If environmental reforms had only a limited effect on human development and could not be passed on to future generations, then true progress could be achieved only by improving the racial stock. Conditions such as epilepsy, "feeblemindedness," mental deficiency, alcoholism, immorality,

2. Mark Haller, Eugenics: Hereditarian Attitudes in American Thought (New Brunswick, NJ, 1963), 8-9. 
sexual perversion, and prostitution were generally regarded in the nineteenth century as threats to social stability. Moreover, advocates of eugenics identified such conditions as genetic traits, and many of them believed "feebleminded" and backward individuals to be more fecund than normal people. Civilization, therefore, could be improved gradually by eliminating undesirable genes from the human gene pool and encouraging the propagation of the fit. ${ }^{3}$

The eugenics movement gained popularity in many countries, including the United States, Canada, Denmark, Germany, Sweden, Norway, Finland, Mexico, Japan, and France. Eugenics quickly legitimized itself as a science by establishing research centers, foundations, professional journals, and international conferences. The Eugenics Education Society of England was formed in 1907 and founded its own journal, Eugenics Review, in 1910. Because of the widespread interest in the subject, the Eugenics Education Society sponsored a highly publicized International Congress of Eugenics in 1912, which attracted more than eight hundred scientists and social scientists from throughout the world. ${ }^{4}$

The American eugenics movement was allied with the international movement, but branched into various styles of thought and action and repeatedly redefined itself during the early part of the twentieth century. Perhaps the most significant event in the history of American eugenics was the creation of the Station for Experimental Evolution at Cold Spring Harbor, New York. The Carnegie Institute of Washington established the station in 1904 and appointed Charles Davenport as director. Davenport had been an instructor of biology at Harvard and, later, at the University of Chicago. His enthusiasm for eugenics and his interest in the work of Galton and Karl Pearson, one of Galton's disciples, led Davenport to the station. Through his position there and as the secretary of the Committee on Eugenics of the American Breeders' Association, Davenport organized commit-

3. G. R. Searle, Eugenics and Politics in Britain, 1900-1914 (Leyden, The Netherlands, 1976), 6-7.

4. Phillip Reilly, The Surgical Solution: A History of Involuntary Sterilization in the United States (Baltimore, 1991), 103; Haller, Eugenics, 20. 
tees to promote studies on heredity at universities and institutions around the country. Included in his list of recruits were Alexander Graham Bell, who led the committee on "deafmutism," and Adolf Meyer and Elmer E. Southard, who were leading American psychiatrists. Robert Yerkes, a Harvard psychologist, and Frederick Thorndike, a biologist at the Massachusetts Institute of Technology, were among those involved in research on the inheritance of mental traits. Davenport's committees also included experts on criminality and sociology as well as members of the Immigration Restriction League and superintendents of penal and mental institutions. These committees were largely responsible for expanding the study of human genetics in the United States. In 1910 Davenport sought funding from the philanthropist Mrs. E. H. Harriman to create a Eugenics Record Office at Cold Spring Harbor, which became the center of eugenic propaganda and research in the United States. The American Eugenics Society, which was organized in the early 1920s, worked closely with the Eugenics Record Office as a public relations organization. These organizations received funding and support from the highly respected foundations of the Rockefellers, Carnegies, and Kelloggs, among others. ${ }^{5}$

Perhaps the greatest single promoter of eugenic sterilization statutes in the United States was Harry Laughlin. Born in Oskaloosa, Iowa, Laughlin attended Iowa State College but received no degree. In Kirksville, Missouri, he became a teacher of agriculture and biology. Laughlin was intrigued by developments in genetics in part because of the promise they held for the agricultural sciences and his breeding experiments with poultry. In 1907 Laughlin wrote to Charles Davenport to learn more about eugenics. That correspondence led to a professional relationship between the two men. Eventually, Laughlin was invited to head the newly created Eugenics Record Office. There his lifelong crusade for eugenic sterilization began. With his team of field workers, Laughlin directed the collection of extensive pedigrees, family histories, state and local social surveys, and psychometric testing results. He used the information (or sometimes misinformation) amassed by the Eugenics Record

5. Haller, Eugenics, 63-65, 73, 126, 173. 
Office to promote and document the need for eugenic sterilization in the United States. Laughlin made his case in extensive writings and speaking engagements. His testimony before the House Committee on Immigration and Naturalization undoubtedly influenced the passage of the Immigration Act of 1924, which restricted the immigration of "weak stock" from eastern and southern Europe. By the early 1920s, Laughlin had emerged as the national expert, primary advocate, and principal force behind the passage of sterilization laws around the country, including Iowa. ${ }^{6}$

Organizing public interest was an important step in realizing eugenical philosophies in each state. Laughlin received significant support from the social activists of popular eugenics, a movement dominated by progressive philanthropists and women. During the 1920s and 1930s several private organizations, such as Birthright and the Human Betterment League, formed to advertise the social benefits of sterilization. They found a receptive audience in progressive Americans dedicated to social reform, realism, and the eradication of human ills. The belief that human ability and success were determined by genetics and not environment could account for both the superiority of middle-class and upper-class whites and the inferiority of those who deviated from the white, middle-class standard. Notions of natural equality were at odds with the basic tenets of eugenics.

The American eugenics movement amounted to a strong indictment of people who were poor, uneducated, or foreignborn, members of racial minorities, or people with mental disabilities. They were the target of proposals for marriage restriction, permanent custody, and sexual sterilization. Most American eugenicists, however, regarded marriage restriction and incarceration as impractical, expensive, and ineffective. Consequently, sterilization became the primary focus of the American eugenics movement, even though Sir Francis Galton's philosophy maintained that increasing the productivity of "the best stock" was far more important than restricting the productivity of the "worst."

6. J. David Smith, Minds Made Feeble (Rockville, MD, 1985), 138.

7. Sir Francis Galton, Inquiries into Human Faculty and Its Development (New York, 1907), 219. 
Eugenicists advocated state laws that would make it possible to sterilize any potential parent of socially inadequate offspring. They promised that sterilization laws would eliminate defective genes from the nation's gene pool and prevent the creation of children who could not be adequately cared for. Furthermore, because children who could not be adequately cared for would inevitably become wards of the state and, later, prostitutes and criminals, sterilization promised future economic benefits, saving tax dollars that were being unnecessarily wasted on poor relief.

Eugenical propaganda was remarkably successful. Between 1907 and 1940 twenty-seven states, including Iowa, passed laws reflecting the national and international interest in eugenics. According to Phillip Reilly's study of involuntary sterilization, more than sixty thousand people were sterilized in the United States without their consent for specifically eugenical purposes between 1907 and 1960. Public institutions and state legislatures were responsible for administering the eugenical programs advocated by Davenport, Laughlin, and the social activists of popular eugenics. Superintendents of facilities for the insane and feebleminded, prison wardens, and social workers were largely responsible for implementing eugenical sterilization in the United States. Although American eugenicists disassociated themselves from Nazi Germany's sterilization program, under which 71,960 persons were sterilized in 1935 alone, the laws they advocated also used state control to monitor the procreation of their nation's citizens. ${ }^{8}$

THE MOVEMENT from propaganda to state law came in two distinct stages. The early laws (1907-1920) were largely punitive, including provisions for the sterilization of criminals. By 1929, seven of these early laws had been overturned in court deci-

8. Reilly, Surgical Solution, 2; Haller, Eugenics, 5. Stefan Kühl's The Nazi Connection (Oxford, 1994), is a study of American influence on and aid to early Nazi sterilization programs. This connection to Germany was played down by American eugenicists during and after World War II, because they wished to disassociate themselves from Hitler's actions. Kühl argues that American historians have not adequately acknowledged the relationship between the two. 
sions. Later laws, aimed primarily at people with mental disabilities, were therapeutic rather than punitive. A variety of factors contributed to the passage of state sterilization laws, including lobbying efforts, publications, and successful, albeit illegal, experimentation. Dr. Harry C. Sharp, surgeon for the Indiana Reformatory, for example, announced at the National Prison Association Conference in 1907 that he had performed 223 vasectomies without any surgical complications. That year Indiana became the first state to enact a sterilization statute, which became a model for other states. ${ }^{9}$

Iowa's first sterilization law, passed in 1911, was approved by a large majority in the House and unanimously in the Senate. Perhaps the most inclusive sterilization law passed in the country, it provided for the sterilization of "habitual criminals, degenerates and other persons." Regular physical and mental examinations were ordered for those in the custody or care of the state who were "criminals, rapists, idiots, feeble-minded, imbeciles, lunatics, drunkards, drug fiends, epileptics, syphilitics, moral and sexual perverts, and diseased and degenerate persons" and who might produce "children with a tendency to disease, deformity, crime, insanity, feeble-mindedness, idiocy, imbecility, epilepsy or alcoholism." It was the duty of the parole boards to judge whether or not it was "improper or inadvisable to allow any of such inmates to procreate." The law also allowed for the sterilization of convicted prostitutes and twiceconvicted felons. Following the national trend, the law specified vasectomy and salpingectomy (tubal ligation) as the preferred methods of operation on men and women respectively. ${ }^{10}$

The early sterilization laws tended to affect more men than women, perhaps because these laws were primarily focused on the problem of the male criminal and the sterilization of institutionalized people. There were generally more men than women confined in correctional institutions. The term female degenerates often referred to prostitutes, who were likely to be infertile from chronic venereal disease infections, which surgeon and eugeni-

9. Haller, Eugenics, 50, 135-39, 180.

10. Supplement to the Code of Iowa (1913), sec. 2600; Daniel Kevles, In the Name of Eugenics (Berkeley, CA, 1985), 100. 
cist A. J. Ochsner argued were natural protections against degenerate offspring. Finally, salpingectomy was a more costly and more dangerous procedure than vasectomy, and therefore was less frequently used. ${ }^{11}$

In the 1913 case of Davis v. Berry, a federal court declared that Iowa's 1911 law, like many other early state sterilization laws, was unconstitutional. The judge determined that the law imposed cruel and unusual punishment, violated the due process clause, and was a bill of attainder. He compared vasectomy to castration. "The physical suffering may not be as great, but ... the humiliation, the degradation will follow him wheresoever he may go. This belongs in the dark ages." ${ }^{12}$ The law of 1911 was replaced in 1915 by a statute that applied only to inmates of hospitals for the insane and required consent of a relative. According to information collected by Harry Laughlin, between 1911 and 1921 forty-nine people were sterilized in Iowa under these laws. In approximately the same time period, 2,558 people were sterilized under California law. ${ }^{13}$

Harry Laughlin's sterilization campaign was often challenged, even by those in the business of promoting eugenics. In 1920 the national board of the Woman's Christian Temperance Union (WCTU) arrived in Iowa City to spell out the details of a grant it had allocated to the Iowa Child Welfare Research Station, a research branch of the University of Iowa. The purpose of the grant was to establish a Department of Eugenics that would study the impact of heredity and environment on childhood development, investigate the "recommended mental, moral, and physical traits of suitable marriage partners," and formulate "norms and standards of child development for young fathers and mothers." Bird T. Baldwin, the director of the Iowa Child Welfare Research Station, was reportedly relieved to discover that "his guests [from the WCTU] did not accept the kind of ultranationalistic and racist eugenics then being peddled by the leaders of the scientific branch of the eugenics movement." According to historian Hamilton Cravens,

11. Reilly, The Surgical Solution, 34.

12. Davis v. Berry, 216 Federal Reporter 413 (S.D. Iowa 1914).

13. Reilly, Surgical Solution, 49. 
the representatives from the WCTU identified eugenics with "socialization into proper habits of health, diet, and sobriety for the young, plus a need to watch out for partners of the opposite sex who came from the wrong side of the tracks, had peculiar relatives or otherwise did not conform to community standards of 'being nice."' Baldwin, in fact, subsequently rejected Harry Laughlin as a candidate for professor of eugenics because of his poor scientific standards. ${ }^{14}$

Several other private activist organizations emerged in the 1930 s to disseminate information on the benefits of sterilization and to promote government sterilization programs. Among them were the Sterilization League of New Jersey (later known as Birthright, Inc.) and the Human Betterment League. Birthright was founded in 1937 by two sterilization advocates: Marion Norton Olden, a zealous social activist, and James Gamble, a wealthy physician and heir to the Proctor and Gamble soap fortune. ${ }^{15}$ The Human Betterment Foundation, a separate organization which funded the Human Betterment League, was founded in California by Eugene Gosney, a wealthy businessman and eugenics enthusiast. The foundation was closely allied with the international movement, particularly in Germany. Several of the reports Gosney published on sterilization programs in California later appeared in German editions. ${ }^{16}$

Combined with "scientific" advances in genetic research and sterilization procedures, these social components contributed to the success of the American eugenics movement. The joint efforts of state boards, legislators, mental institutions, relief workers, and activist individuals and organizations resulted in the passage and successful implementation of a second round of sterilization laws to replace those that had been found unconstitutional. Under these new laws, sterilization was enacted for therapeutic, rather than punitive, purposes.

14. Hamilton Cravens, Before Head Start: The Iowa Station and America's Children (Chapel Hill, NC, 1993), 36-37.

15. Thomas Shapiro, Population Control Politics (Philadelphia, 1985), 55.

16. Kühl, Nazi Connection, 25, 43. 
IOWA remained in stride with the rest of the nation when its legislature created its Board of Eugenics in 1929. The board consisted of the Commissioner of Public Health, the medical director of the Psychopathic Hospital in Iowa City, and the superintendents of the following institutions: the Institution for Feebleminded Children at Glenwood, the Hospital for Epileptics and Feebleminded at Woodward, the Women's Reformatory at Rockwell City, and the four hospitals for the insane at Cherokee, Clarinda, Independence, and Mount Pleasant. The directors of each state correctional facility were to report to the board all persons who were "feeble-minded, insane, syphilitic, habitual criminals, moral degenerates, or sexual perverts and who are a menace to society" and who might produce children who were likely to become "a social menace or ward of the state."17 Between 1934 and 1977, the Board of Eugenics authorized the sterilization of more than two thousand men and women in Iowa (see table).

Public reaction to the law is difficult to gauge. Widespread support apparently did not truly emerge until the 1940s. In 1933 University of Iowa political scientist N. W. McGee dismissed the eugenics law in Iowa as a "dead letter" because it failed to provide an effective administrative body. McGee also noted that members of the board were so scattered about the state that meeting regularly would be difficult. ${ }^{18}$ Apparently they did not convene at all until 1934, when the board's records begin. They subsequently met quarterly in Des Moines to decide cases brought before them.

The function of the board was to grant approval for sterilization, not to find suitable candidates. The various state institutions were responsible for referring appropriate cases to the board. In order for a case to be considered by the board, an application for sterilization was required. Typically, the hospital superintendent, physician, local attorney, or relief worker who referred the patient to the board completed the application. It was signed by the patient or the patient's relative or appointed

17. Code of Iowa, (1931), sec. 2437.

18. N. W. McGee, "State Administration of Public Health in Iowa," Iowa Journal of History and Politics 31 (1933), 200-201. 
guardian, depending on the mental capacity of the patient. Mental incapacity, which could result from a wide assortment of conditions, was apparently determined by the board. An important development at the time was psychometric testing, particularly the Binet test, which measured the intelligence quotient (IQ) of a patient. By comparing a patient's chronological age with his or her mental age, it provided physicians with a numerical standard of innate intelligence and provided a more legitimately scientific basis for sterilization. ${ }^{19}$

Following the application were mental and physical examinations, including the Binet test and an interview to collect information on family history. Such data was needed to determine if a patient's condition was hereditary and likely to be passed on to future generations. When this data had been gathered, the board reviewed the case and pronounced its approval or disapproval of sterilization. Diagnoses by a physician or psychiatrist that led to sterilization included, in the terms of the time, feeblemindedness, mental deficiency, psychosis, epilepsy, chronic brain syndrome, organic brain disease, alcoholism, and moral degeneracy. The definition of some of these conditions is unclear. The term feebleminded was used to indicate a variety of mental disabilities and inclinations toward deviant behavior. Case records would sometimes simply state, "dull-normal, inadequate type." In several cases, there was no diagnosis given, but a remark such as "socio-economic basis" was written to the side. Indeed, any indication that a candidate would be unable to care adequately for future progeny was justification for sterilization, provided the patient would agree. ${ }^{20}$

Especially in the first twenty years of the board's existence, IQ scores weighed heavily in decisions to approve sterilization, despite differing opinions on the value of the tests and the standards for scoring. ${ }^{21}$ In 1938 the Iowa Child Welfare Research Station received national attention for work suggesting that IQ was not fixed from birth to death, but could be increased with

19. Haller, Eugenics, 96-99.

20. Applications for Sterilization, 1934-1974, Iowa Board of Eugenics Records; Kevles, In the Name of Eugenics, 78.

21. Haller, Eugenics, 100. 
nurturing. Consequently, the roles of heredity and environment in human development were still unclear. George Stoddard of the Iowa Station argued that "the pessimists of science and society ... should not be permitted to limit the potentiality of every American citizen" but should "unlock the unique potentialities of every person." 22 This claim so contradicted conventional wisdom that it was ignored by many scientists and academics until the 1950s.

Technically, all of the cases that came before the Iowa Board of Eugenics were voluntary, meaning that the patient and a relative had to give consent. In this respect, Iowa laws were different from other state laws. Virginia law, for example, provided for compulsory sterilization for eugenic and therapeutic purposes. In a now famous case, the compulsory Virginia law was challenged when Carrie Buck, a "feebleminded" woman and single mother who had herself been born out of wedlock, refused to be sterilized. In 1927 the appealed case came before the United States Supreme Court, which sustained the constitutionality of the Virginia law and ordered Carrie Buck's sterilization. Justice Oliver Wendell Holmes wrote in the majority opinion, "It is better for all the world, if instead of waiting to execute degenerate offspring for crime or to let them starve for their imbecility, society can prevent those who are manifestly unfit from continuing their kind." The case was a major victory for the eugenicists. Harry Laughlin, who wrote a book on the proceeding, said the decision meant that "eugenical sterilization, properly safeguarded, is a logical exercise of the police power inherent in each of the 48 states of the Union." ${ }^{23}$

In Iowa, a patient or patient's relative could refuse the operation. When that happened, the cases were usually dropped, especially if the refusal came from a parent. But refusals were somewhat unusual, especially in the first twenty years of the board's existence. Although the Iowa law was intended to be voluntary, there were undoubtedly instances when patients felt they had little choice. Paroles, for instance, often depended on

22. Cravens, Before Head Start, 186-88, 200.

23. Harry Laughlin, The Legal Status of Eugenical Sterilization (Chicago, 1930), 52-53. 
the institutionalized person's agreement to be sterilized. Comments such as "parents anxious to have daughter back home," included with the case record of one parole candidate, suggest how the board, a doctor, or a social worker may have influenced the decision to give consent for sterilization. ${ }^{24}$

The first case to come before the Board of Eugenics was one of the most unusual in its history. The case involved a twentyfour-year-old man (hereafter referred to as Lionel, a pseudonym) who had been charged with statutory rape in $1934 .^{25}$ The magistrate in the case offered Lionel the option of being sterilized as an alternative to prosecution for rape. Lionel was examined by a physician and a psychologist who determined that he should, indeed, be sterilized. Wishing to avoid prison and an unpleasant trial, Lionel and his father gave their consent for the operation. Several months later, they appeared before the Board of Eugenics and were questioned at length about Lionel's crime, his life, his choice to be sterilized, and his understanding of the procedure.

Lionel testified that he had had sexual intercourse with his sixteen-year-old girlfriend, whom he had hoped to marry. The girl's father had registered the complaint against him, and he was brought before the county court. Lionel was asked to give a brief history of his life, apparently to determine the possibility of hereditary degeneracy. He explained that, after quitting school in the eighth grade, he had gone to work in a broom factory, where he had been employed for seven years. He lived at home and gave his earnings to his mother and his father, a railroad laborer. There were six children in the family.

Lionel's father was asked if they were voluntarily applying for the operation. He replied, "We really did not, but had some difficulty, that is why Mr. Shankland [the magistrate in the case] had it fixed up, so he decided it." Lionel's appointed attorney explained to the board that the recommendation for sterilization was not meant to be a punishment, but "a social regulation to improve future generations."

24. Minutes, 1937, Iowa Board of Eugenics Records.

25. The following account is based on Minutes, 1934, Iowa Board of Eugenics Records. 
The board unanimously confirmed the doctors' recommendation. Lionel was "feebleminded definitely and of the moron level. The general prospect is that he will require economic, social and moral supervision." The chairman of the board felt compelled to explain the psychological report to Lionel. "We want you to understand, Lionel ... the substance of the report is that you are a little backward in schoolwork and you are classified as a backward individual." Several board members felt that it was wrong for them to decide Lionel's punishment or to allow his crime to go unpunished, but all agreed that sterilization was in order. Much of the discussion and disagreement surrounding Lionel's case seemed to be a reflection of the board's inexperience and uncertainty about its authority. Nevertheless, Lionel underwent a vasectomy one month after the hearing.

The circumstances surrounding Lionel's case were unusual. The sterilization was approved, in part, as a punitive measure. That was not typical after the first round of sterilization laws was overturned. However, the unusually lengthy discussion among board members provides insight into their motivations and demonstrates the substantial influence that state officials and doctors had over a candidate's decision. Lionel seemed to agree with the experts' conclusion that he was "backward" and unfit to propagate, even though he had earlier expressed an interest in marriage. Even in more typical circumstances, other patients may have been persuaded to believe in their own deviancy, backwardness, or incompetence, and thus may have seen no viable alternative to sterilization.

In some situations, patients may not have understood that they were going to be sterilized. In 1946 a 34-year-old Mexican woman "suffering from sleeplessness, restlessness and making scenes on the street" was taken to one of Iowa's state hospitals for the insane. The physician who examined her noted that the mental examination was complicated by the fact that neither she nor her husband spoke English. Nevertheless, her husband gave his consent by signing the application, and she was sterilized. ${ }^{26}$

The eugenics movement in America and abroad influenced considerations of immigration and "the race problem." In Iowa,

26. Minutes, 1946, Iowa Board of Eugenics Records. 
perhaps because of the state's rather homogeneous population, race was a subtle and inconsistent determinant in sterilization cases. ${ }^{27}$ Although records of the few non-white patients who came before the board routinely noted the patient's race, usually as "Colored" or "Mexican," concern for "racial pollution" or consciousness of a race problem was not evident in either patient records or board meeting minutes. Moral degeneracy and parental incompetence were not clearly linked to color or ethnicity. In a 1935 case the board did not approve the sterilization of a "big, black, burly, greasy-looking Negro" from the state penitentiary, despite the physician's description and the patient's criminal record. ${ }^{28}$

By the 1930s, Iowa's eugenics campaigns differed in tone and practice from the rhetoric of zealous activists such as Harry Laughlin that defined the American eugenics movement. Rather than consciously pursuing the abstract goal of cleansing the gene pool of bad elements, Iowa's eugenics advocates were attempting to address real problems in their communities. The basic motivation behind both state action and private efforts in Iowa was to ease the burden of what eugenics advocates considered an inferior class of social dependents who would inevitably produce further generations of socially dependent, incompetent parents. The attempt to eliminate poverty and mental disability through sterilization was an extreme exercise of class consciousness, bizarre altruism, and social justice. That many residents of public mental institutions were poor and that state laws were aimed at institutionalized people further contributed to the disproportionate application of sterilization laws to the poor. ${ }^{29}$

AFTER WORLD WAR II, the eugenics movement in the United States quieted. As Stefan Kühl points out, many American eugenicists were anxious to disassociate themselves from

27. According to the 1940 federal census, Iowa's population was 99.3 percent white; 4.6 of the total population was recorded as foreign born.

28. Minutes, 1935, Iowa Board of Eugenics Records.

29. Kevles, In the Name of Eugenics, 167-68. 
Hitler's human breeding experiments. By the late 1940s, eugenics had begun to lose credibility among established birth control organizations and in the medical community. ${ }^{30}$ However, eugenical sentiments remained surprisingly popular after World War II, despite the disclosure of Nazi atrocities and the change in American attitudes. In terms of private activism and public sentiment, a reorientation of tactics was designed to focus less on traditional hereditarian eugenics and more on socioeconomic conditions. While the idea of eliminating "bad genes" was increasingly viewed as obsolete, the desire to reduce the number of inadequate parents and socially burdensome children remained intact.

Compulsory sterilization was consistently rejected by Planned Parenthood, which isolated eugenic sterilization from the mainstream birth control and population control movement. Private, national organizations such as Birthright and the $\mathrm{Hu}-$ man Betterment League, which campaigned for sterilization in Iowa and other states, were beginning to reconstruct their agendas. By 1943, Marion Norton Olden of Birthright, Inc., was already being pushed into the background for being "too parochial and unscientific" and embarrassing the organization with her "backward" views on compulsory sterilization. ${ }^{31}$

In Iowa, voluntary sterilization did not gain wide popularity until after World War II, when the reorientation of these organizations had already begun to take place. The number of sterilizations approved by the Iowa Board of Eugenics increased with the visibility and activity of private, national organizations, such as the Human Betterment League and Birthright. These organizations worked in conjunction with state and local agencies, including Iowa's State Board of Eugenics, to facilitate the sterilization of people with mental disabilities. By selectively promoting sterilization as a voluntary method of contraception, it remained a viable eugenic tool without appearing too unenlightened.

The Human Betterment League was a national organization committed to eugenic sterilization and population control. Its

30. Kühl, Nazi Connection; Shapiro, Population Control Politics, 55-58.

31. Shapiro, Population Control Politics, 55-56. 
Iowa chapter was established in the 1940s and remained active until at least $1970 .{ }^{32}$ During the late 1930s and the 1940s, eugenic sterilization seems to have become largely a women's issue, dominated by activists rather than scientists. Members in Iowa worked directly with at least nine social agencies to facilitate sterilization procedures and to distribute educational materials, as well as to serve as an "unofficial auxiliary" to the State Board of Eugenics. In 1950 the board hired a woman from the Des Moines Human Betterment League to work part-time under the board's auspices as a social worker, with her salary paid by the Iowa Mental Health Authority. ${ }^{33}$ These women activists, in many cases, were apparently qualified by nothing more than personal zeal and were self-educated on the benefits of sterilization.

The League actively sought public support for its activities. Through mass mailings, it targeted social welfare boards, high school and college students, nurses, lawyers, and ministers. A press release issued by the League in 1949 pointed out the advantages of vigorous sterilization programs. "Surgical sterilization," it claimed, "has allowed 'feebleminded' patients in California 72,771 years of life outside of institutions since 1918 and saved the state $\$ 21,831,000$." The League's newsletter reported in 1954 that its booth at the Iowa State Fair had been a great success. Many fair attendees had expressed their support for the League's work, indicating approval by a substantial portion of the general public. ${ }^{34}$

The national organizations maintained contact with their chapters through salaried field workers, field reports, newsletters, and traveling lecturers. In 1945 Birthright hired as its

32. Information on the Iowa Human Betterment League (IHBL) is difficult to locate, and little mention of the organization is made in the records of the Board of Eugenics. According to 1970 board minutes, a woman who was refused the operation by the board was referred to the IHBL. At that time, the organization was described in the minutes as providing "information and financial assistance on sterilization." On a national level, the Human Betterment League was replaced by the Association for Voluntary Sterilization in the 1960s, when it came under the leadership of medical professionals rather than social activists.

33. Minutes, 1950, Iowa Board of Eugenics Records.

34. Reilly, Surgical Solution, 137; Human Betterment League of Iowa Newsletter, 1954, University of Iowa Special Collections. 


\begin{tabular}{|c|c|}
\hline $\begin{array}{l}\text { money, } \\
\text { the job of parenthood is too } \\
\text { much to expect of feeble- } \\
\text { minded men and women. }\end{array}$ & $\begin{array}{l}\text { Having a healthy, } \\
\text { normal baby is the } \\
\text { most important } \\
\text { of all jobs - } \\
\text { It is also } \\
\text { important that } \\
\text { babies have good } \\
\text { physical care and } \\
\text { loving, thoughtful } \\
\text { guidance }\end{array}$ \\
\hline $\begin{array}{l}\text { Mental defectives who are } \\
\text { sterilized may marry and lead } \\
\text { satisfactory lives. } \\
\text { Often they may become rea- } \\
\text { sonably self-supporting if } \\
\text { they are spared the responsi- } \\
\text { bility of parenthood- }\end{array}$ & $\begin{array}{l}\text { Seleetive } \\
\text { Sterilization } \\
\text { aloo protects children } \\
\text { for no child should be born } \\
\text { to subnormal parents - de- } \\
\text { nied a fair, healthy start in } \\
\text { life - or doomed from birth } \\
\text { to a mental institution. }\end{array}$ \\
\hline $\begin{array}{l}\text { The Human Betterment Leagn } \\
\text { to urge public support for Iowa } \\
\text { assured readers that selective } \\
\text { it "protects [Iowa's] mentally } \\
\text { of future generations, and the } \\
\text { of taxpayers dollars, needless } \\
\text { chure (probably from the late } \\
\text { ments Collection, Special Coll }\end{array}$ & $\begin{array}{l}\text { stributed an 18-page brochure } \\
\text { "terilization Law. The brochure } \\
\text { "is not barnyard castration!"; } \\
\text { men and women, the children } \\
\text { at large [and] saves thousands } \\
\text { ly, and wasted lives." The bro- } \\
\text { y 1950s) is in the Social Docu- } \\
\text { versity of Iowa Libraries. }\end{array}$ \\
\hline
\end{tabular}


field secretary for Iowa Elizabeth Bond of Des Moines, who was described as a "widow with nursing training." Her salary was underwritten by a Massachusetts philanthropist. Bond's duties included visiting major institutions for mental patients, helping state workers select cases for the board, and making appointments for psychometric testing of patients. The June 1945 field report stated that a 25 percent increase in sterilizations ordered at the last meeting of the State Eugenics Board was a result of Bond's promotional efforts. Overall, sterilizations increased only slightly in 1945 and decreased in the following year. Bond attributed this to a lack of competent institutional staff and social service workers. In addition to activities designed specifically to increase the number of authorized sterilizations, Bond was responsible for educating community leaders and ordinary citizens about the benefits of eugenics. For example, she surveyed the "chronically indigent" families of Des Moines to determine, among other things, how much these families cost taxpayers. And in 1946 the head of the Iowa State Psychology Department invited Bond to speak to faculty and students in the honorary psychology fraternity. She noted the enthusiasm with which her lecture was received, particularly by the young faculty members who had just returned from armed service. ${ }^{35}$

The results of such efforts were considerable. A report of the Human Betterment League in 1957 boasted that, in four states where the League had been active (Iowa, Nebraska, North Carolina, and Georgia), sterilization had increased 146 percent between 1948 and $1951{ }^{36}$ Iowa's statistics support this assertion (see table). In fact, while most state sterilization programs reached their peak in the late thirties, Iowa's peak came precisely in the years of League activity.

The mission of private organizations such as the Human Betterment League was to find suitable candidates for sterilization. Since it was not illegal for a person to seek sterilization without the approval of the State Board of Eugenics, it seems

35. Box 1, folder 7, and box 2, folder 10, Association for Voluntary Sterilization Papers, Social Welfare History Archives, University of Minnesota, Minneapolis.

36. Human Betterment League of Iowa, Inc., Non-serial file, Social Documents Collection, Special Collections, University of Iowa Libraries, Iowa City. 
TABLE 1

PERSONS STERILIZED UNDER THE STATE BOARD OF EUGENICS IN IOWA, 1934-1974

\begin{tabular}{cccccccc}
\hline Year & Male & Female & Total & Year & Male & Female & Total \\
\hline 1934 & 1 & - & 1 & 1955 & 6 & 38 & 44 \\
1935 & 2 & - & 2 & 1956 & 16 & 67 & 83 \\
1936 & 1 & 8 & 9 & 1957 & 7 & 41 & 48 \\
1937 & 9 & 37 & 46 & 1958 & 1 & 21 & 22 \\
1938 & 9 & 28 & 37 & 1959 & 1 & 14 & 15 \\
1939 & 7 & 33 & 40 & 1960 & 9 & 16 & 25 \\
1940 & 26 & 79 & 105 & 1961 & 26 & 18 & 44 \\
1941 & 23 & 80 & 103 & 1962 & 4 & 24 & 28 \\
1942 & 19 & 52 & 71 & 1963 & 3 & 27 & 30 \\
1943 & 18 & 55 & 73 & 1964 & 1 & 20 & 21 \\
1944 & 24 & 22 & 46 & 1965 & 2 & 16 & 18 \\
1945 & 17 & 34 & 51 & 1966 & 1 & 16 & 17 \\
1946 & 7 & 39 & 46 & 1967 & - & 13 & 13 \\
1947 & 13 & 61 & 74 & 1968 & 1 & 10 & 11 \\
1948 & 36 & 112 & 148 & 1969 & - & 5 & 5 \\
1949 & 61 & 103 & 164 & 1970 & 9 & 37 & 46 \\
1950 & 35 & 96 & 131 & 1971 & 15 & 44 & 59 \\
1951 & 54 & 140 & 194 & 1972 & 7 & 25 & 32 \\
1952 & 28 & 81 & 109 & 1973 & 14 & 32 & 46 \\
1953 & 16 & 55 & 71 & 1974 & 6 & 3 & 9 \\
1954 & 7 & 41 & 48 & TOTAL & $\mathbf{5 4 2}$ & $\mathbf{1 6 4 3}$ & $\mathbf{2 1 8 5}$ \\
\hline
\end{tabular}

SOURCE: Minutes, Statistics, and Agendas, 1956-1976, Iowa Board of Eugenics Records.

that the only unique function of the board was its authority to sterilize institutionalized persons who were incapable of giving consent or who had no guardian to give consent. However, its mere existence signifies the importance placed on sterilization as a means to social betterment. The board undoubtedly facilitated the legal process of sterilization for the institutionalized and provided a social service for the noninstitutionalized who could not otherwise afford the procedure.

The ideology of both Birthright and the Human Betterment League contained a strong Protestant element. In a pamphlet titled "A Moral Basis for Eugenic Sterilization," distributed by the Human Betterment League of Iowa, Unitarian minister Charles W. Phillips argued that God would not want man to allow the suffering of the unfit and their children to continue 
if it was within human means to stop it. Sterilization of the unfit was a humanitarian action. A 1945 pamphlet issued by Birthright stated, "Humanitarianism is wholly vicious . . . when it insists upon human equality to the extent of according the same rights and privileges to the feebleminded, the insane and the criminalistic as to the mentally and physically sound, the economically capable and the socially minded. ${ }^{\prime \prime 3}$

The debate over eugenic sterilization was a source of conflict between the already divided Protestants and Catholics. At the time, birth control was emerging as a major point of contention between these two groups. The Catholic Church, as well as church-affiliated groups such as the Knights of Columbus, were outspoken in their opposition to contraception and sterilization of the unfit. ${ }^{38}$ A 1946 Birthright field report cited the high percentage of Catholics and "greater restriction of the discussion of things sexual" as major barriers to progress in Iowa. The fact that Birthright was an out-of-state organization was an additional factor in the resistance of some Iowans to the issue of sterilization. ${ }^{39}$ Several cases that came before the board were dismissed because of objections from Catholics. ${ }^{40}$ While many of the "experts" and visible people who spoke on behalf of the Human Betterment League were men (and often Protestant ministers or prominent church members), the membership seems to have been composed largely of middle-class and upper-class women.

Approximately 75 percent of the reported sterilizations approved by the Iowa Board of Eugenics were performed on women (see table). Out of a sample of 50 case records spanning the board's entire existence, 41 were women, 38 were institution-

37. Birthright, Inc., Non-serial file, Social Documents Collection, Special Collections, University of Iowa Libraries, Iowa City.

38. Reilly, Surgical Solution, 118-22.

39. According to Phillip Reilly, Surgical Solution, 133-34, Clarence Gamble of Birthright set up more than twenty sterilization clinics in the Midwest and South, including Iowa, Indiana, Michigan, Missouri, Kansas, Nebraska, and Florida, although I could find no evidence that a sterilization clinic existed in Iowa. In Puerto Rico, he established private clinics that provided birth control services and sterilization procedures. The Dight Institute at the University of Minnesota has a large collection of records on Birthright.

40. Minutes, 1945, Iowa Board of Eugenics Records. 
alized patients (rather than outside referrals), 34 were single, 11 were married, and 5 were divorced. The average age for women was 23 , for men 27 , and overall 24 . One girl was sterilized at eleven years of age. ${ }^{41}$

The activity of organizations such as the Human Betterment League very likely contributed to the board's tendency to focus on the sterilization of women. By actively pursuing social welfare agencies in search of candidates to refer to the board, more women-especially more single mothers - were undoubtedly included. It became increasingly common in the 1940s for women to be referred to the board by county welfare agencies or a town's director of relief or overseer of the poor. Preventing female pregnancy was a more immediate concern than preventing male fatherhood in both institutionalized and noninstitutionalized cases. Women were sometimes admitted to mental institutions for the sole purpose of being sterilized. Once the possibility of pregnancy was eliminated, a woman could be safely discharged. Similarly, if a woman married, she constituted less of a social risk. One patient in 1950 who had married after the application was signed saw her case dismissed despite her "psychopathic trends" and "borderline intelligence." 42 The Human Betterment League, in particular, viewed sterilization as a broad solution to a range of social problems. Poverty, illegitimacy, illiteracy, sexual and moral misbehavior, and even mental disabilities all deviated from the white, Protestant, middle-class cultural standard and created a social burden.

In Iowa, as in other states, many sterilizations were probably conducted without the knowledge or approval of the Board of Eugenics, but the extent to which physicians acted independently is unknown. On February 15, 1976, the Des Moines Register ran a story on the Jasper County Home revealing the abuse of patients, including scalding deaths and involuntary sterilization. The story mentioned the case of a woman named Robin Woody who was confined to the home in 1971. At the age of eighteen,

41. Applications for Sterilization, 1934-1974, Iowa Board of Eugenics Records. The applications for sterilization reviewed by the board are filed alphabetically. For this sample I used the first fifty cards filed under the letter "M." 42. Minutes, December 1950, Board of Eugenics Records. 
Woody was sterilized against her will, not because of any mental disability, but because she was an "impulsive, hairtriggered young girl" and a "questionable risk" for child rearing. Woody's release from the home was contingent on her consent to sterilization. ${ }^{43}$

At the time that the Register article appeared, the Board of Eugenics said that they had never "approved a sterilization for anyone who was unruly or a discipline problem," only the severely retarded. Dr. Roy Sloan, the home's physician, said that he had made his recommendation for the surgery based on his assessment of the patient's ability to be a parent. Dr. Sloan could not remember how many residents were sterilized during his eight-year tenure, but he said that all were women and a number were not retarded. A short time after her release, Woody told a nurse from the hospital that she was discharged because she agreed to give up her right to be a person. ${ }^{44}$

This case demonstrates how a physician or superintendent might have had the power to act independently and suggests that many cases went unreported. Sentiments such as those represented by the Woody case were not, however, widely endorsed by the medical community or by the Iowa Board of Eugenics. Yet the publicity and embarrassment surrounding such incidents ultimately contributed to the discrediting of sterilization as a socioeconomic panacea. After 1960, the Iowa Board of Eugenics became increasingly selective about approving sterilizations. By the late 1960s, sterilizations approved by the board were performed almost exclusively on institutionalized persons, in particular on those patients who could not manage living independently and were sexually active.

Even earlier than the sixties, efforts were made to redefine private organizations such as Birthright and the Human Betterment League to distance them from their more radical elements. Birthright's executive committee dismissed Marion Olden in 1948 so that the organization could be run by "professionals and doctors." In 1965 the Human Betterment League became the Association for Voluntary Sterilization, which remains active

43. Howard v. Des Moines Register and Tribune Co., 283 N.W.2d 289 (Iowa 1979). 44. Ibid. 
today. By the late 1960s, most of the private organizations had either died out or altered their message, employing new terminology to advocate sterilization as a means of family planning, world population control, and environmental management. Both compulsory and voluntary sterilization had become issues of social justice. The former was a violation of personal liberty, the latter a means of personal empowerment. ${ }^{45}$

A variety of reasons explain the decline of compulsory sterilization. The fact that birth control was being more publicly discussed and was more widely available is one. Sterilization and contraception became associated with a fundamental aspect of feminism - a woman's right to control her own fertility. There was also a change both in the scientific world and in public welfare ideology concerning the role of environment in the development of the individual. The War on Poverty, for instance, proclaimed that the problems of the poor could be mitigated through environmental intervention; the conditions that produced poverty would thus not be passed on to the next generation through genetic heredity. Finally, individualism and the rights of the individual were redefined in the postwar era in such a way that the white, middle-class cultural standard of the Human Betterment League was no longer the ideal, but the subject of criticism.

The Iowa State Board of Eugenics continued to function until 1976, when the board members drafted a resolution calling for its dissolution. Judging from its records, the board was largely inactive during the last few years of its existence. Included in the final resolution was a provision to establish boards within each state institution to decide sterilization cases. The board resolved that a "preponderant number of experts in human genetics" believed that selective sterilization had little effect on the human genetic pool, that "only a few causes of mental retardation or mental illness" were clearly genetic, and that every person had the right to control their own reproduction. ${ }^{46}$ Acceding to the board's request, the Sixty-seventh General

45. Shapiro, Population Control Politics, 54-56.

46. Minutes, 1976, Iowa Board of Eugenics. 
Assembly, by a unanimous vote in both the House and Senate, formally abolished the board in 1977 .

THE HISTORY OF THE IOWA BOARD OF EUGENICS, even though it took place entirely within this century, seems to reveal a great ideological gap between the past and present. We must be cautious, however, about our judgments of the past and our assumptions about human progress toward the present. There can be little question from the perspective of the present that eugenic sterilization, as it was promoted in Iowa by the State Board of Eugenics, amounted to social and economic discrimination. Yet such contemporary social dilemmas as controlling illegitimacy and population explosion, genetic testing, and other reproductive issues suggest that technological development continues to outpace ethical and moral reflection. Eugenics must not be simply discarded as a mistake of yesterday. The individuals who participated in the activities of the Human Betterment League, Birthright, and the Board of Eugenics believed that their efforts would contribute to a more progressive civilization. Fundamental for understanding eugenic sterilization is that, throughout its history, human liberties were violated in the name of science and a well-intentioned solution for contributing to the greater good of the human race. 
Copyright of Annals of Iowa is the property of State of Iowa, by \& through the State Historical Society of Iowa and its content may not be copied or emailed to multiple sites or posted to a listserv without the copyright holder's express written permission. However, users may print, download, or email articles for individual use. 